\title{
Family resilience and chemical dependency: perception of mental health professionals
}

\author{
Resiliência familiar e dependência química: percepção de profissionais de saúde mental \\ Resiliencia familiar y dependencia química: percepción de profesionales de salud mental \\ Sonia Regina Zerbetto', Sueli Aparecida Frari Galera", Bianca Oliveira Ruiz' \\ ' Universidade Federal de São Carlos, Postgraduate Program in Nursing. São Carlos, São Paulo, Brazil. \\ "Universidade de São Paulo, Ribeirão Preto College of Nursing, \\ Department of Psychiatric Nursing and Human Sciences. Ribeirão Preto, São Paulo, Brazil.
}

\section{How to cite this article:}

Zerbetto SR, Galera SAF, Ruiz BO. Family resilience and chemical dependency: perception of mental health professionals. Rev Bras Enferm [Internet]. 2017;70(6):1184-90. DOI: http://dx.doi.org/10.1590/0034-7167-2016-0476

Submission: 08-19-2016 Approval: 02-05-2017

\begin{abstract}
Objective: To learn the perception of health professionals from the Psychosocial Attention Center for Alcohol and Other Drugs regarding the resilience attributes that are critical to family members of psychoactive substance dependents. Method: A qualitative descriptive study conducted from February to May 2016, using a focus group technique for data collection. In total, 15 professionals participated in the study: 13 health professionals and two administrative professionals. The statements were recorded and transcribed, and these data were analyzed using the technique of thematic content analysis. Results: Health professionals recognize the family resilience attributes needed for efficient and assertive communication, as well as organizational patterns and facilitating family strengths, factors that contribute to improved family relationship and family functionality. Final considerations: This study contributed to a perspective of clinical intervention with family members that is not limited to the negative aspects of family relationship and life, such as fragility and family dysfunction.
\end{abstract}

Descriptors: Family; Psychological Resilience; Substance-Related Disorders; Mental Health; Health Personnel.

\section{RESUMO}

Objetivo: Conhecer a percepção dos profissionais de saúde de Centro de Atenção Psicossocial - Álcool e Outras Drogas sobre atributos fundamentais de resiliência das famílias de dependentes de substâncias psicoativas. Método: Estudo qualitativo, descritivo, realizado em fevereiro e maio de 2016, através da técnica de grupo focal para coleta de dados. Participaram 15 trabalhadores: 13 da área de saúde e 2 da administração. Os relatos foram gravados por áudio, transcritos e os dados foram analisados pela técnica de análise de conteúdo temática. Resultados: As equipes de saúde reconhecem os atributos da resiliência familiar que perpassam os domínios da comunicação eficiente e assertiva, padrões organizacionais e forças familiares facilitadoras, fatores que auxiliam na melhora da relação familiar e de sua funcionalidade. Considerações finais: $\mathrm{O}$ estudo contribuiu para uma perspectiva de intervenção clínica com familiares que não se limita a aspectos negativos da relação e convivência familiar, tais como fragilidades e disfuncionalidade familiar.

Descritores: Família; Resiliência Psicológica; Transtornos Relacionados ao Uso de Substâncias; Saúde Mental; Pessoal de Saúde.

\section{RESUMEN}

Objetivo: Conocer la percepción de profesionales de salud de Centro de Atención Psicosocial - Alcohol y Otras Drogas sobre atributos fundamentales de resiliencia de familias de dependientes de substancias psicoactivas. Método: Estudio cualitativo, descriptivo, realizado en febrero y mayo de 2016, mediante técnica de grupo focal para recolección de datos. Participaron 15 trabajadores: 13 del área de salud y 2 administrativos. Testimonios grabados en audio y transcriptos, datos analizados por análisis de contenido temático. Resultados: Los equipos de salud reconocen los atributos de la resiliencia familiar que atraviesan los dominios de comunicación eficiente y asertiva, estándares organizacionales y fuerzas familiares facilitadoras, factores que permiten mejorar la relación familiar y su funcionalidad. Consideraciones finales: El estudio contribuyó a una 
perspectiva de intervención clínica con familiares no limitada a aspectos negativos de la relación y convivencia familiar, tales como debilidades y disfuncionalidad familiar.

Descriptores: Familia; Resiliencia Psicológica; Trastornos Relacionados con Sustancias; Salud Mental; Personal de Salud.

\section{CORRESPONDING AUTHOR Sonia Regina Zerbetto E-mail: szerbetto@hotmail.com}

\section{INTRODUCTION}

In cases of consumption of psychoactive substances, the families of dependents have their functionality impacted by sudden or persistent situations of crisis and stress.

National and international studies about families that experience substance-related problems usually focus on the negative and deficient aspects of the family life, such as fragility, family dysfunction, and characteristics of codependency $y^{(1-7)}$. Therefore, the family is recognized as a risk factor and scenario in view of drug complexity, which requires a targeted approach from health professionals to compensate for family limitations and deficits.

However, few studies have attempted to identify the positive potential and strength of families in the process to cope with, recover from, and overcome adverse situations ${ }^{(8)}$, that is, circumstances that involve family resilience.

Thus it is necessary to care for families and emphasize and strengthen the positive aspects of their lives and functioning, even in adverse contexts, as well as to identify and value the way these families address these situations and solve their problems in the context of psychoactive substance dependence.

Therefore, the concept of family resilience is a reference for the work developed by mental health professionals-more precisely in the services of psychosocial care network.

Considering the above, the objective of this study was to learn about the perception of health professionals from the Psychosocial Attention Center-Alcohol and Other Drugs (CAPS-ad) regarding the resilience attributes that are critical to family members of psychoactive substance dependents in therapy follow-up that help improve the family relationship and functionality.

\section{METHOD}

\section{Ethical aspects}

The ethical and legal principles of research involving human beings were respected, according to Resolution $\mathrm{n}^{\circ}$ $466 / 2012$. This study was approved by the Ethics Research Committee in 2015. All participants signed an Informed Consent Form after the study objectives and data collection technique were explained to them.

\section{Theoretical framework}

The theoretical framework of family resilience in the systemic perspective of Froma Walsh was used for data collection and analysis in this study.

Family resilience in the systemic view comprises a network of interactions and experiences throughout life and between generations, which strengthens the family group as a functional unit. The way a family copes and deals with adverse experiences and efficiently reorganizes itself will influence the family group, which contributes to the resilience of all of its members ${ }^{(8-10)}$. Family resilience involves the potential for strength, restructuring, recovery, and growth in families that face adversity and severe life challenges ${ }^{(8-10)}$.

The critical elements of family resilience involve the family belief system, organizational patterns, and communication processes. The belief system involves the perceptions and actions of family members in an adverse or challenging situation. Organizational patterns are related to the strategies used by the family to restructure life and mobilize internal and external resources for effective responses to the roles and tasks that are required of them. Communication processes are facilitating resources that enable family functioning, allowing emotional expressions and open and clear reactions, and encouraging collaborative problem solving and conflict resolution ${ }^{(8,10)}$.

\section{Study design}

This is a qualitative descriptive study.

\section{Methodological procedures}

\section{Study site}

This study was conducted in two CAPS-ad facilities belonging to the Regional Department of Health (DRS) in the countryside of the State of São Paulo. One of the CAPS-ads belonging to the respective DRS did not show interest in participating in this study for team reformulation reasons.

\section{Data source}

The two focus groups comprised four health professionals from one service and 11 from another. Of these, nine were health professionals and two were administrative professionals. The inclusion criteria were: permanent and/or temporary employment bond, aged 18 years or older. The exclusion criteria were: professionals on maternity or sick leave during the data collection period.

\section{Data collection and organization}

A focus group was used as the data collection technique, based on which the group interaction creates discussions and considerations on a certain theme, with collection of perceptions and experiences of its participants. According to this technique, the group had at least four and up to $12 \mathrm{mem}$ bers, in addition to the researcher/moderator and observer, arranged in a circle. The researcher/moderator had the role of encouraging group interaction and debate, while the observer was responsible for recording verbal and non-verbal information $^{(11-12)}$. In this study, five meetings were held with each group in the facilities of each CAPS-ad. 
The group meetings were scheduled during the team meetings, according to the schedules of the researchers and professionals, and conducted from February to May 2016, intercalated weekly between the CAPS-ad meetings, lasting one hour and 30 minutes; the statements were recorded. The topics for group discussion involved concepts of resilience, identification of family resilience, family strategies to cope with adversity, and the health professional's role in strengthening family resilience.

The statements were recorded and transcribed. After a session with each focus group a content summary from the previous meeting was presented for validation of the professionals. The statements of interviewees were coded with the letter $\mathrm{P}$ for "professional," with a number from 1 to 15 given to each participant.

\section{Data analysis}

The technique of content analysis was used in data treatment $^{(13)}$ and the interviews were read line by line. Nuclei of meaning (themes) with the same semantic content were identified, which presented constitutive elements of family resilience, with the support of analytical indicators of communication systems, organizational patterns, and facilitating beliefs from the Froma Walsh theory.

In light of the theoretical framework of family resilience, three categories were obtained: efficient and assertive communication; role of leadership and support; and family strength.

\section{RESULTS}

Regarding the participant characterization, a total of 15 professionals working in the CAPS-ad, of these two were from the administrative area (administrative assistant) and 13 from the health area (nurse, social worker, occupational therapist, psychologist, nursing assistant). No physician was included due to the tight schedules of these professionals and double-shift demands in another service. Female health professionals were predominant (10). Of the total, 13 had up to 15 years of experience in the health area and 13 up to five years in the area of mental health. Regarding the working time in CAPS-ad, 14 had been there for up to five years. These two CAPS-ads had been recently built, which justified the short duration of professional experience.

Data analysis led to the creation of three categories: efficient and assertive communication; role of leadership and support; and family strength.

\section{Efficient and assertive communication}

The professionals highlighted that the family members' style of communication with the patient will have an impact on the behavior of both. Communication becomes assertive when it is no longer aggressive and confrontational. The following statement also showed that the professional recognized his important therapeutic role when he helped the family find ways to establish assertive communication:

I guess they [husband and wife] are developing an assertive communication; what used to be passive or aggressive before is now assertive. We [health professional] have found ways to make them [the couple] understand, without fighting, without conflict or speaking aggressively. She [wife] has chosen assertiveness. She has changed and consequently it has an impact on her behavior and on his behavior [husband]. [...] they start to understand that perhaps the language they use at home doesn't bring good understanding. Sometimes they talk, but are not understood. Sometimes, with a simple change in the way of speaking. [...] but she understood that her way of speaking makes a difference in the way he reacts, the way he places himself. I guess it's positive. (P12)

For health professionals, the resilient family expressed its messages in an open, thoughtful and calm manner, despite situations of great emotional tension. The identified problem was communicated and shared with the involved member, enabling support for him through counseling. The statement also highlighted that efficient communication was a skill that enabled appropriate interventions recognized by the patient as help:

In the family, I guess each individual has certain skills. Perhaps if the guy is drunk, he [family member] can talk. Perhaps he can talk calmly, give advice, help. Perhaps a calm person can intervene and help him [patient] and he [patient] thinks that's a proper help. "Oh! You see what you did yesterday? I had to hold you." Perhaps at the end he will spend time talking to him [patient]: "Look what you are doing with your life". (P4)

In the perception of the interviewees, the resilient family shared a problem collectively, which made its resilience even stronger:

I guess, collectively, the family may also become stronger, to the extent that the family of a chemical dependent will sit with them and ask: "What's going on?". (P3)

\section{Role of leadership and support}

For one professional, the communication established between a family member-in this case the son-and his family also helped understand the role he assumed in the family organization, helping other members-that is, his parents-solve an intra-family problem. This attitude can be especially evident when weak parents are not able to make a decision. Despite being a son and a young adult, the individual was also able to take the lead in conducting a family negotiation and supporting the other members in handling a critical situation. However, the professional stressed that there are roles and responsibilities that parents should assume, not delegate to their children:

His role of pushing his parents, I guess he's with his parents to think of this family. I don't think it's negative. I guess this 23-year-old son may even assume the role of a family member, of saying: "Oh! When the [patient's name] comes back, let's talk about it, OK?" And in this family, it's very characteristic, the children talk about it. I don't think it should always start with the parents. It's an adult who said [...] that the parents are weak; they don't know how to manage this situation. I guess that, for instance, if the boy would come and address his returning sister: "Look, we found out about these things, maybe we [...] all these things are happening," then, all right, I guess that talking about that with [patient's name] is the role of the parents. But, giving this support, how we will deal with 
this situation, assist a member who needs help, I guess these other people who are involved, the two older children, who are adults, can be together, too. I don't see any problem; I don't see that it changed roles. (P3)

Another family role recognized by health professionals is to seek resources for the patient that involved emotional, social, and economic support networks. The family identified the type of support and mobilized the members to search for resources from intra-family and/or extra-family support networks, allowing simultaneous resilience strengthening. This way, the family also assumed a supporting role to its members:

What help does this person [the patient] need? Is it a more emotional support or support of other nature, such as financial, from other family members and society, then I guess the family gets stronger in this sense of becoming resilient in order to address this situation. (P1)

The role of the family as a treatment partner has been recognized in the family's willingness to understand and support the patient in moments of major family conflict, and when coping with the physical consequences of the drug effects:

And then it's putting the family role into this sense of being together in the treatment, also of being available to understand all of these situations and offer the son support in how to cope, for example, with the abstinence effects. In the group [of family members], they [the mothers] talk a lot about it [...] in a situation of marital conflict, family conflict, how will the family offer support to them [patients] in this sense? (P2)

\section{Family strength}

Another positive element identified by the health teams that addresses the family organization involved the ideas of family mobilization, unity, and support, which constitute family strength collectivism with the goal of saving the life of the patient in treatment and leading to changes in this person:

There is also this idea: "we will never let someone from the family get lost in life; we have to rescue this person." There is this idea of rescue. And in this sense, there is the idea of family strength as a supporting element. I guess it has a dimension of strength from this perspective [...] as if somehow [...] the existence of a collective in itself has the idea of support, then, in this type, it mobilizes someone to a possible change. (P6)

We notice the strength [...] that one person mobilizes the other people in the family. We see this question of family collectivism, pushing one another. One helps the other, and it mobilizes the others to perform a certain action. (P7)

The dimension of strength also appeared in another statement showing that the family hopes to believe in the patient's recovery. No matter whether the family is united or segregated, they showed possibilities of positive strength to increase family resilience and help the family solve its problems:

What I understand in terms of strength is that regardless of the family being a group or being fragmented, it's the hope of patient recovery. Then I guess it is based on the patient's improvement, finding this strength to try to reach resilience and try to solve the problem. (P5)

The statements highlighted that families impacted by adversity recovered from this impact and created new ways to deal with situations of crisis. In their understanding, this circular movement was characterized by family persistence and perseverance in attending CAPS-ad and showing motivational attitudes:

The family's persistence in suffering the impact and recovering from this impact and creating a new way to cope with it will depend on the patient's results in the proposals that have been made. Most families I see, they don't give up. One or two people in the family keep insisting on having the patient out, to give the patient treatment, and come to the service, trying to hospitalize, trying to bring the patient here and take them to church. (P8)

Their [family members] persistence in being here in the service, I guess it's positive. Even though they come and say: "I won't do anything else. I'll abandon him [patient]," they never fulfill this promise of abandonment. They come back. (P12)

The persevering and supporting attitudes of families with the patients consisted in encouraging treatment continuity, attending CAPS-ad, not giving up or abandoning the patients, and seeking religious support or hospitalization.

\section{DISCUSSION}

The health professionals involved in this study perceived critical attributes of family resilience in the dimensions of communication, organizational patterns, and family strength with an impact on the relational process and family functionality. Such positive and effective elements have helped family members cope with and overcome adverse situations and challenges during their own treatment and that of their family member. For the professionals, these elements allowed a careful and therapeutic look at the identification of positive family strength, which strengthened family resilience.

In this study, the health professionals recognized that an assertive and non-aggressive communication style provided a positive and effective impact on the family interaction process. This was in agreement with studies on family resilience with members diagnosed with severe mental disorders ${ }^{(14)}$ and family interactions in the context of alcoholism ${ }^{(15)}$. From the theoretical perspective of family resilience, in the systemic view, family functionality is effective when members communicate in a respectful and thoughtful manner, using a proper tone of voice, and showing an open emotional expression ${ }^{(8,10)}$, as identified by the teams in this study.

When family members communicate openly and share their doubts, desires, and suffering in an effective, clear, and objective manner among themselves, it is possible to better understand the nature of adverse or problematic situations. In this sense, family members may seek a positive resolution inside or outside the family context. The ability of each family 
member to effectively express and share sincere and directive emotions and attitudes for collective problem solving constitutes the attributes of family resilience ${ }^{(14,16)}$. When the family expresses and responds to its concerns and needs in an assertive, open, and respectful manner, it minimizes the risk of intra-family conflicts and promotes family cohesion and a safe environment for (re)negotiating changes in the system and solving problems. In addition, changes in the communication style, attitudes, and behaviors of a family member are seen in family interactions, changing the family environment and social context. Such impact influences family attitudes and behaviors and creates circularity. According to the systemic theory and family resilience approach, a family member with positive skills and perspectives who is informed in situations of crisis can encourage other family members to change this environment and lead all family members to adopt similar behaviors.

Such positive and virtuous circularity is seen in the organizational patterns of the family when promoting unity, and sharing difficult moments and possibilities of (re)building new roles and rules in this new functionality.

The statements of the health professionals in this study showed the restructuring of a family when, in moments of crisis that require a decision, one of the members assumed the leadership role and helped the family handle the critical situation. However, it was not a behavior of domination over the other members, but a possibility to provide an opportunity for dialogue and share feelings, doubts, and strategies so that the family, as a functional unit, could cope with that situation in a more effective manner. From the perspective of the health professionals in this study, there was no role reversal that characterized an impact on the hierarchy and generational limits, for example, the child assuming the role of the father. According to the health professional, it was a situation of cooperation and mutual support to help the parents.

According to the theory of family resilience, from the systemic perspective good family functioning requires flexible organization of its roles and rules, but it should always keep a dynamic balance between change and stability ${ }^{(8,10,17)}$. To balance stability and change, the leadership role can be shared, with proper rules according to age and without emotional or physical overload, by a family member ${ }^{(8,10)}$. The statements of the participants in this study agreed with the concepts found in the literature when the attributes of family resilience involved solidarity, family interconnection for teamwork, redistribution or adjustment of individual roles, and division of tasks and responsibilities. These characterized a collective effort of the family to reach goals, seek resources, and solve problems ${ }^{(8,10,15-16)}$.

From the perception of the health professionals, the family members, when joining and mobilizing, were able to think of the impact of the critical situation they were experiencing. This factor allowed them to identify and seek sources of emotional or financial support, as well as support from other family members, extended family, or the community. Their perception and ability to identify and use social support networks and other resources is called resourcefulness, which is

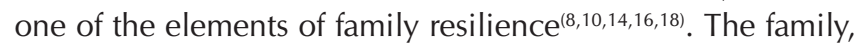

when accepting help from the social support network and affective bonds-whether from relatives, friends, or neighbors; from health services; or religious, school, recreational, and leisure organizations, among others-allowed open and active connections. These included the dimensions of information (through counseling, guidance, information), emotion (expression of affection, respect, feelings and desires), instrumental (financial support, availability of assets and services), and positive social interaction (availability of people) ${ }^{(19)}$.

This family role as a source of support, identified by the health teams in this study, placed the family as a partner in the patient's treatment through its physical and emotional availability.

Another element of family resilience identified by the health professionals in this study was family strength. According to the statements, the family strength was positive, involving domains of organizational patterns and facilitating beliefs.

Regarding family organization, its strength was understood by the health professionals in this study as unity among the members to support and to rescue lives.

The literature emphasizes that, in adverse situations, the family unit restructures itself, reorganizing its system and improving its strength ${ }^{(8)}$. Then it has a sense of cohesion and mobilization that strengthens the family. Thus the families, in adverse and challenging situations, were united to seek internal and external resources to cope with and overcome those challenges.

Regarding the systemic perspective, the family built resilience in an interactional process, based on family strengths resulting from family cohesion ${ }^{(20)}$, understood as unity of its members or emotional connection between them ${ }^{(15)}$. A study defines family resilience as the family's ability to trigger and mobilize strength when the life of a member is threatened by a critical and stressful event ${ }^{(16)}$. This definition suits this study, because the family sought to rescue the lives of those with chemical dependency.

Family strength is defined as a family's competence in the process of positively coping with adverse situations and challenges in daily life ${ }^{(21)}$ in such a way as to improve family functionality and integrality. Thus this strength becomes a mechanism of family resilience, which requires of its members, even in adverse situations, the ability to effectively respond to possible demands.

In the process of rescuing the lives of family members who are psychoactive substance dependents, the health teams believed that families remained optimistic about the recovery of their relatives. The family members remained persistent and perseverant in the treatment, attended CAPS-ad, motivating the patients to engage in and adhere to the treatment, and seeking religious support or even hospitalization.

In the approach to family resilience, hope, perseverance, persistence, courage, and encouragement are situated in the domains of belief systems, as they enable the construction of family strength for the process of coping, recovery, and overcoming adversity ${ }^{(8,10)}$. Facilitating beliefs shared among family members contribute to resilience because they impact the family's "healthy and effective" way to deal with adversity, and the consequences of such actions influence the maintenance of positive beliefs ${ }^{(22)}$.

The families mentioned in this study, when remaining optimistic about the recovery of their patients, found strength to persist, persevere, and encourage the patient to participate 
in treatment and provided patient support. Indeed, remaining hopeful in a critical and adverse situation motivates families to continue fighting for positive perspectives and outcomes ${ }^{(8,10,23)}$. Thus hope is understood as a driving strength when seeking solutions for problems and coping with adverse situations ${ }^{(18)}$.

In the statements of health professionals, the family's hope was maintained as the patient improved, that is, if the patient adhered to treatment, remained abstinent, or reduced drug use. Therefore, hope, perseverance, persistence, and courage were maintained when there was a positive perspective resulting from the effective treatment of the patient, which reinforced the family's positive or facilitating beliefs. Positive thinking is effectively reinforced by successful experiences ${ }^{(8,10)}$. Therefore, health professionals should promote positive beliefs, in addition to praising the strength of both patients and families. In this sense, positive thinking encouraged everyone in the family to seek strength that motivated them to believe in their problem solving abilities and possibilities. In addition, the presence of positive results promoted optimism and confidence; and helped increase and reinforce the self-esteem, selfefficacy, perseverance, hope, and courage of the family group.

The literature shows that perseverance and persistence indicate the ability of family members to resist adversity in difficult moments. It is understood as a motivating and determining force in the process of coping with and overcoming adversity ${ }^{(8,10)}$.

Courage and encouragement are positive forces that lead the family group to remain involved in the patient's therapeutic follow-up, face the challenges related to drug addiction with confidence, and have the courage to confront and combat situations related to the fear of crisis, treatment uncertainties, and fear of constant patient relapse. The families face contexts of stress that can make them vulnerable to negative emotions $^{(23)}$. Such situations require therapeutic interventions to encourage and strengthen their resilience, because when considering the systemic perspective, the courage of one family member may impact the courage of other members ${ }^{(8,10)}$.

\section{Study limitations}

The study limitations refer to the failure to include all CAPS-ad from the studied DRS and all health professionals, such as physicians. Considering family resilience a transactional process over time, we suggest future longitudinal studies with the goal of capturing the experience of health teams in the follow-up of these families. It is necessary to identify the elements of resilience in the moments that precede the interventions of health professionals, to confirm whether the care provided to the families contributes to the process of coping with the adverse situations of chemical dependency and strengthens family resilience.

\section{Contributions to the health field}

The results of this study contribute to a perspective on clinical interventions with family members who experience the problem of substance dependence, which is not limited to the negative aspects of family relationship and living, such as fragility and family dysfunction.

\section{FINAL CONSIDERATIONS}

This study showed the perception of the health professionals from the CAPS-ad, regarding critical attributes of family resilience in the context of psychoactive substance dependence, that help improve family relationships and functionality.

The professionals involved in this study understood that the elements of family resilience were present in the fields of assertive communication, organizational patterns, and facilitating family strength.

The health teams in this study recognized their therapeutic role in strengthening family communication skills. This fact reinforced the need for a clinical practice that recognizes and appreciates this attribute of family resilience, and it promoted family strength and family support in its process of structural and functional organization.

\section{REFERENCES}

1. Paz FM, Colossi PM. Aspectos da dinâmica da família com dependência química. Estud psicol [Internet]. 2013 [cited 2016 Jan 23];18(4):551-58. Available from: http://www.scielo.br/pdf/epsic/v18n4/a02v18n4.pdf

2. Seleghim MR, Oliveira MLF. Influence of the family environment on individuals who use crack. Acta Paul Enferm [Internet]. 2013[cited 2016 Feb 23];26(3):263-68. Available from: http://www.scielo.br/pdf/ape/v26n3/en_10.pdf

3. Orford J, Velleman R, Natera G, Templeton L, Copello A. Addiction in the family is a major but neglected contributor to the global burden of adult ill-health. Soc Sci Med [Internet]. 2013[cited 2016 Jun 20];78:70-7. Available from: http://www.sciencedirect.com/ science/article/pii/S0277953612007988

4. Caravaca-Morera JA, Padilha MI. A dinâmica das relações familiares de moradores de rua usuários de crack. Saúde Debate [Internet]. 2015[cited 2016 Jan 02];39(106):748-59. Available from: http://www.scielo.br/pdf/sdeb/v39n106/0103-1104sdeb-39-106-00748.pdf

5. Bortolon CB, Signor L, Moreira TC, Figueiró LR, Benchaya MC, Machado CA, et al. Family functioning and health issues associated with codependency in families of drug users. Ciênc Saúde Colet[Internet]. 2016[cited 2016 Jan 02];21(1):101-07. Available from: http://www.scielo.br/pdf/csc/v21n1/1413-8123-csc-21-01-0101.pdf

6. Askian P, Krauss SE, Baba M, Kadir RA, Sharghi HM. Characteristics of co-dependence among wives of persons with substance use disorder in Iran. Int J Ment Health Addiction[Internet]. 2016[cited 2016 Aug 30];14(3):268-83. Available from: https://link.springer. com/article/10.1007/s11469-016-9631-0 
7. Abasi I, Mohammadkhani P. Family risk factors among women with addiction-related problems: an integrative review. Int J High Risk Behav Addict [Internet]. 2016[cited 2016 Aug 10];5(2):e27071. Available from: http://jhrba.com/?page = article\&article_id=27071

8. Walsh F. Family resilience: strengths forged through adversity. In: Walsh F. Normal family processes. London: The Guilford Press; 2012. p.399-423.

9. Walsh F. Family Resilience: a framework for clinical practice. Fam Process [Internet]. 2003[cited 2014 Oct 23];42(1):1-18. Available from: http://www.celf.ucla.edu/2010_conference_articles/Walsh_2003.pdf

10. Walsh F. Fortalecendo a resiliência familiar. São Paulo: Roca; 2005.

11. Santos MRM, Sousa CS, Turrini RNT. Perception of orthognathic surgery patients on postoperative care. Rev Esc Enferm USP [Internet]. 2012[cited 2016 Aug 10];46(Spe):78-85. Available from: http://www.scielo.br/pdf/reeusp/v46nspe/en_12.pdf

12. Bordini GS, Sperb TM. Grupos focais online e pesquisa em psicologia: revisão de estudos empíricos entre 2001 e 2011. Interação Psicol [Internet]. 2013[cited 2016 Aug 06];17(2):195-05. Available from: http://revistas.ufpr.br/psicologia/article/ view/28480/22695

13. Minayo MCS. O desafio do conhecimento: pesquisa qualitativa em saúde. 13th ed. São Paulo: Hucitec; 2012.

14. Bishop M, Greeff AP. Resilience in families in which a member has been diagnosed with schizophrenia. J Psychiatr Ment Health Nurs [Internet]. 2015[cited 2016 Apr 10];22(7):463-71. Available from: http://onlinelibrary.wiley.com/doi/10.1111/jpm.12230/ epdf

15. Silva P, Silva M, Luz G. Protective family interactions to cope with alcoholic condition: bases for nursing work. Rev Enferm UERJ [Internet]. 2012[cited 2016 Jul 25];20(2):191-6. Available from: http://www.e-publicacoes.uerj.br/index.php/enfermagemuerj/ article/view/4043/2808

16. Oh S, Chang SJ. Concept analysis: family resilience. Open J Nurs[Internet]. 2014[cited 2016 Jul 25];4(13):980-90. Available from: http://file.scirp.org/pdf/OJN 2014122613582460.pdf

17. Wright LM, Leahey M. Enfermeiras e famílias: um guia para avaliação e intervenção na família. Spada S(trad.). 5th ed. São Paulo: ROCA; 2013.

18. Zauszniewski JA, Bekhet AB, Suresky MJ. Indicators of resilience in family members of adults with serious mental illness. Psychiatr Clin North Am [Internet]. 2015[cited 2016 Jul 25];38(1):131-46. Available from: http://www.sciencedirect.com/science/article/ pii/S0193953X14001063?via\%3Dihub

19. Bullock K. Family social support: conceptual frameworks for nursing practice to promote and protect health. In: Bomar PJ. Promoting health in families: applying family research and theory to nursing practice. 3rd ed. Philadelphia: Saunders; 2004. p.142-61.

20. Valdez CR, Abegglen J, Hauser CT. 'Fortalezas familiares' program: building sociocultural and family strengths in latin women with depression and their families. Fam Process [Internet]. 2013[cited 2016 Mar 20];52(3):378-93. Available from: http://www. ncbi.nlm.nih.gov/pmc/articles/PMC3775259/pdf/nihms436905.pdf

21. Dias AB, Silva MRS. Processos familiares no contexto do transtorno mental: um estudo sobre as forças da família. Cienc Cuid Saude [Internet]. 2010[cited 2016 Mar 09];9(4):791-98. Available from: http://periodicos.uem.br/ojs/index.php/CiencCuidSaude/ article/view/12047/7199

22. Naressi DA, Girardon-Perlini NMO, Van der Sand ICP, Beuter M, Rosa BVC. Beliefs and resilience in patients who are survivors of leukemia. J Nurs UFPE [Internet]. 2013[cited 2016 Mar 09];7(1):67-75. Available from: http://www.revista.ufpe.br/ revistaenfermagem/index.php/revista/article/view/3253/pdf_1812

23. Ferreira Filho MO, Sá ANP, Rocha IA, Silva VCL, Souto CMRM, Dias MD. Alcoolismo no contexto familiar: estratégias de enfrentamento das idosas usuárias da terapia comunitária. Rev Rene [Internet]. 2012[cited 2016 Mar 09];13(1):26-35. Available from: http://www.repositorio.ufc.br/bitstream/riufc/12691/1/2012_art_moferreirafilha.pdf 